\title{
Differentiation Potential of Adipose-Derived Mesenchymal Stem Cells to Osteoblast Cell in Early, Middle and Late Passages
}

\section{Rilianawati $\mathbf{R}^{1 *}$, Jennifer Bratakencana ${ }^{1}$ and Ago Harlim²}

${ }^{1}$ Center of Pharmaceutical and Medical Technology, Agency for the Assessment and Application of Technology, Jakarta, Indonesia

${ }^{2}$ Dermatovenereology department, Christian Universitas of Indonesia, Jakarta, Indonesia

\begin{abstract}
Human adipose tissue is a great source of mesenchymal stem cells. Adipose-derived mesenchymal stem cells (AD-MSCs) are easily isolated, able to differentiate into multi-lineage cells and have various clinical application. This promising potential will be more valuable for the application of tissue engineering if they can be sequentially subcultured without loss of phenotype and multilineage differentiation ability. Thus, in this study we investigated the ability of human AD-MSCs to differentiate into osteogenic lineage by performing histological staining and studied the osteogenic potential of human AD-MSCs on early (P2, P5), middle (P10) and late passage (P15). Cells were cultured in osteogenic medium for 2 weeks and characterized at 1, 4, 7, 10 and 14 days. During sequential subcultivation, ADMSCs were able to maintain their osteogenic potential through late passage. AD-MSCs in middle passage exhibited a better osteogenic potential than the early and late passages, while the AD-MSCs from P2 are less differentiated than middle and late passages. The result that was found in this research should be accounted for when developing stem cell-based therapies for clinical application
\end{abstract}

Keywords: Adipose-derived mesenchymal stem cell; Mesenchymal stem cell, Differentiation; Osteoblast cell

\section{Introduction}

Bone tissue has the ability to regenerate without leaving scars. However, major injury repair of bone tissue caused by trauma, cancer or other bone disease remains a challenge for orthopedic surgeons [1]. Autologous bone transplantation still has deficiencies such as limited autologous tissue available to repair bone damage, donor morbidity, possible wound infections, and longer surgery [2]. An allogenic transplant given to the patient can be a good alternative, but this technique can increase the risk of rejection and disease spread [3]. Therefore, it is necessary to develop a new strategy to improve the technique of bone regeneration.

New developments in the field of cell therapy have provided a new approach in the improvement of bone tissue. Mesenchymal stem cells (MSCs) are multipotent stem cells that can renew themselves and differentiate into several lines, such as adipogenic, condenset and osteogenic precursors [4]. The ability to self-renew and differentiate into osteoblast cells makes the MSCs as a good cell source for bone tissue engineering. Among the various types of MSCs sources, mesenchymal stem cells of adipose tissue origin are multipotent cells that are readily available in abundant amounts and can be isolated by relatively harmless procedures [5]. Establishment of osteoblast cells from MSCs from adipose tissue has tremendous value in developing and evaluating methods to bone regeneration process [1-15].

The application of cell biology and tissue culture generally requires cell proliferation in vitro to obtain sufficient cell numbers, with most studies using stem cells in passages 1 through 5 . However, further research on the MSC capability of adipose tissue origin in maintaining stem cell characteristics and the potential for differentiation in longterm subcultures. Through the above description, this study aims to evaluate the effect of the initial passage (passage $\leq 5$, with passages 2 and 5 ), middle (passages $>5-10$, with passage 10) and old (passage $\geq 15,15$ ) to the differentiation potential of MSC from adipose tissue to osteoblast cells. Osteogenic differentiation in vitro can be done by implanting MSC into induction media. The osteogenesis induction media component generally consists of dexamethasone (DEX), L-ascorbic acid 2 phosphates (ASC) and $\beta$-glycerophosphate ( $\beta$-GP) added to cell culture medium for osteogenic differentiation. Each component has been shown to support MSC osteogenic differentiation in vitro [6].

\section{Material and Methods}

\section{Isolation of MSC of adipose tissue}

Adipose tissue is obtained from a healthy human donor with the approval of a medical action at Clinic with the methodology used already approved by the applicable code of ethics. Adipose fat tissue was isolated enzymatically by collagenase. Incubated at $5 \% \mathrm{CO}_{2}, 37^{\circ} \mathrm{C}$; if the cell reaches $80 \%$ confluency, the cell is ready to use for this experiments (Figure 1).

\section{MSC culture of adipose tissue}

After the isolation process, the MSC of adipose tissue was grown in a growing medium composed of Alpha-Minimum Essential Medium (a-MEM) with supplementation of penicillin-streptomycin and serum incubated at $37^{\circ} \mathrm{C}$ and $5 \% \mathrm{CO}_{2}$ incubator. The growth medium is replaced every 3 days and was calculated (0.05\% trypsin-EDTA; Sigma) when the cell has reached a confluence. Cells are subcultured every 3-5 days and propagated to reach passage 3 .

\section{Optimization of osteogenic media composition}

For optimization of osteogenic media composition, MSC was

*Corresponding author: Rilianawati R, Center of Pharmaceutical and Medical Technology, Agency for the Assessment and Application of Technology, Jakarta Indonesia, Tel: 62-895353263161; Fax: 62-21-7560707; E-mail: liliabbas@gmail. com, rilianawati@bppt.go.id

Received May 07, 2018; Accepted May 18, 2018; Published May 31, 2018

Citation: Rilianawati R, Bratakencana J, Harlim A (2018) Differentiation Potential of Adipose-Derived Mesenchymal Stem Cells to Osteoblast Cell in Early, Middle and Late Passages. J Stem Cell Res Ther 8: 426. doi: 10.4172/2157-7633.1000426

Copyright: (c) 2018 Rilianawati R, et al. This is an open-access article distributed under the terms of the Creative Commons Attribution License, which permits unrestricted use, distribution, and reproduction in any medium, provided the original author and source are credited. 


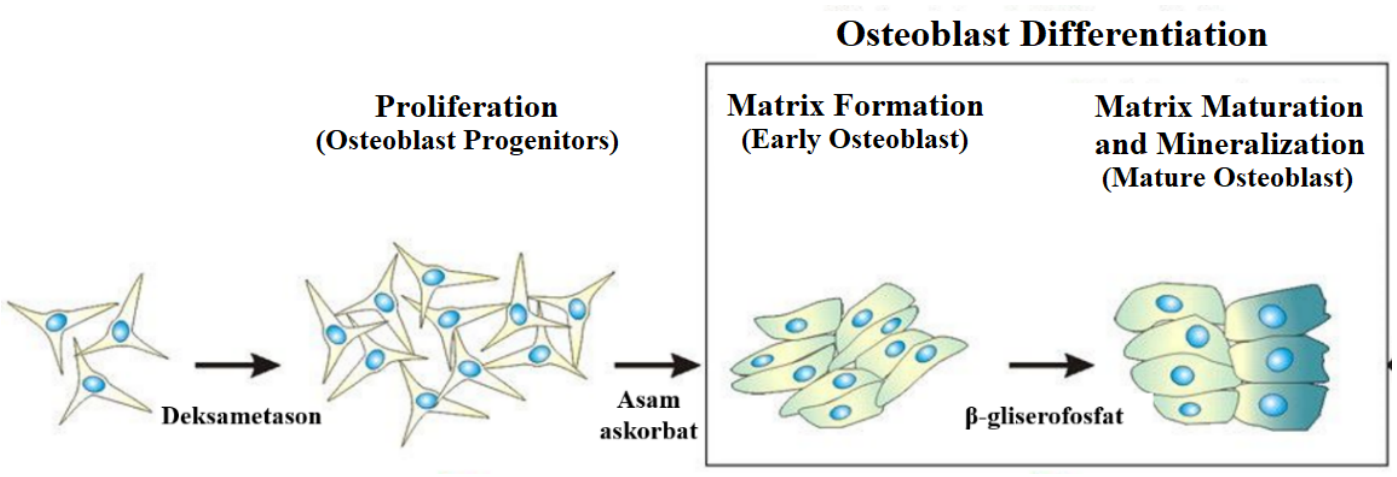

Figure 1: The scheme of forming the MSC stage into osteoblasts and the role of supplements in the induction of osteogenesis.

grown in containers containing growing media supplemented with the following osteogenic components.

For the comparison of each osteogenic medium, the cells were grown in growing media, i.e. $\alpha-M E M+2.5 \%$ serum or $\alpha-M E M+5 \%$ serum and incubated for several hours before initiating differentiation using osteogenic differentiation media [16-30].

\section{Osteogenic differentiation}

Osteogenic differentiation was performed using cell passage variation and incubation time (Tables 1 and 2). Passages used were divided into three groups, namely early passage (passage 2 and 5), middle passage (passage 10), and late passage (passage 15). Each passage is incubated within $1,4,7,10$ and 14 days.

In each incubation time at each passage, there are two dishes consisting of control and treatment. The control media and osteogenic differentiation media used were selected based on the optimum osteogenic composition of the media.

\section{Alizarin red staining}

Cells grown in growth medium and osteogenic media for 1,4 , 7, 10 and 14 days were fixed using formalin $10 \%$ for 24 hours. After fixation, the cell was then stained using Alizarin red dye and incubated for approximately three hours. Visualization of Alizarin red coloring results was performed using an inverted microscope.

\section{Result and Discussion}

\section{Optimization of osteogenic media composition}

Preliminary research was conducted to determine the most efficient osteogenic composition of media in inducing osteogenesis in MSCs of adipose tissue. MSC from passage 3 is grown in different osteogenic media and incubated for five days. After five days, each culture container was characterized using Alizarin red staining (Figure 2).

In Figure 2, it was shown that MSC differentiation results using ODM 1 showed significant differences compared with ODM 2 and ODM 3. In addition, the use of serum with lower concentrations resulted in relatively fewer cell counts than MSCs cultured in concentrations of 5\% serum. Generally, osteogenic differentiation of MSCs in vitro culture is performed using ODM 1 . However, this osteogenic medium was originally used for MSCs differentiation from bone marrow [31-51].

Although MSC from bone marrow and adipose tissue have many similar characteristics, their response to induction factors is not necessarily identical. Therefore, ODM 1 used in this study is still not able to induce osteogenic differentiation well because its component concentration has not been optimized for MSC differentiation of adipose tissue origin. To determine the optimal osteogenic media, ODM 2 and ODM 3 used in this study were made with lower dexamethasone compositions and higher ascorbic acid compared with ODM 1. Based on this research, ODM 2 and ODM 3 may induce osteogenic differentiation more good compared to ODM 1.

The influence of osteogenic media on cell count depends on serum conditions. In the $\alpha-M E M+2.5 \%$ serum condition, the number of cells tends to be less than using $\alpha-M E M+5 \%$ serum. Appropriate serum concentrations are needed to increase cell growth, so the use of serum $2.5 \%$ serum is still not able to support MSC growth optimally.

The characterization results show that ODM 2 using growing media $a-M E M+5 \%$ serum can produce the most optimal osteoblast differentiation compared to other media. This suggests that the results of this study are in accordance with research conducted by de Girolamo. suggesting that higher use of ascorbic acid concentrations and lower dexamethasone may induce osteogenesis in MSCs of adipose tissue well. High concentrations of ascorbic acid are reported to stimulate the proliferation of MSC from bone marrow and cells such as osteoblasts without loss of potential differentiation. Several studies have emphasized the importance of ascorbic acid in osteogenic differentiation of MSC from bone marrow and cells such as osteoblasts. On the other hand, dexamethasone in high concentrations has shown inhibition of osteogenic differentiation, although dexamethasone is required in low concentrations for effective MSC osteogenic induction . Through the above description, the media differentiation used in the next step to induce osteogenic differentiation is ODM 2.

\section{Effect of passage on osteogenic potential of MSC of adipose tissue}

The MSCs from the isolated adipose tissue are then proliferated to certain passages, in passages 2, 10 and 15 . The lifespan of the human MSC can be categorized into the initial passage ( $\leq 5)$, the middle passage $(>5-10)$ and the old passage $(\leq 15)$, based on the proliferative ability and percentage of senescence-associated beta-galactosidase (SA- $\beta$-gal, biomarker for senescence cells), as has been previously proposed. MSC was administered using dexamethasone, 2-phosphate ascorbic acid and $\beta$-glycerophosphate for 14 days to initiate osteogenic differentiation. The osteogenic potential is measured qualitatively by using Alizarin red, which is a colorant that gives color to calcium deposition.

The incubation time is an important factor in determining the 


\begin{tabular}{|c|c|c|}
\hline Media & $\alpha-M E M+5 \%$ serum & $\alpha-M E M+2,5 \%$ serum \\
\hline ODM1 & $\begin{array}{c}100 \mathrm{nM} \text { Dex, } \\
50 \mathrm{\mu g} / \mathrm{mL} \text { Asc, } \\
10 \mathrm{mM} \beta-\mathrm{GP}\end{array}$ & $\begin{array}{c}100 \mathrm{nM} \text { Dex, } \\
50 \mathrm{\mu g} / \mathrm{mL} \text { Asc, } \\
10 \mathrm{mM} \beta-\mathrm{GP}\end{array}$ \\
\hline ODM2 & $\begin{array}{l}10 \mathrm{nM} \text { Dex, } \\
200 \mu \mathrm{M} \text { Asc, } \\
10 \mathrm{mM} \text { ß-GP }\end{array}$ & $\begin{array}{l}10 \mathrm{nM} \text { Dex, } \\
200 \mu \mathrm{M} \text { Asc, } \\
10 \mathrm{mM} \beta-\mathrm{GP}\end{array}$ \\
\hline ODM3 & $\begin{array}{c}5 \mathrm{nM} \text { Dex, } \\
250 \mu \mathrm{M} \text { Asc, } \\
10 \mathrm{mM} \text {-GP }\end{array}$ & $\begin{array}{l}5 \mathrm{nM} \text { Dex, } \\
250 \mu \mathrm{M} \text { Asc, } \\
10 \mathrm{mM} \text { } \beta \text {-GP }\end{array}$ \\
\hline
\end{tabular}

ODM: Osteogenic Differentiation Media; Serum; Dex, dexamethasone; AsA2-F, L-ascorbic acid 2-phosphate; $\beta$-GP, beta-glycerophosphate

Table 1: The composition of the media used in the study.

\begin{tabular}{|c|c|c|c|c|c|}
\hline Passage & \multicolumn{5}{|c|}{ Incubation Time (Day) } \\
\hline Passage 2 & & & & & \\
\hline Passage 5 & \multirow{2}{*}{1} & 4 & 7 & 10 & 14 \\
\hline Passage 10 & & & & & \\
\hline Passage 15 & & & & & \\
\hline
\end{tabular}

Table 2: Optimization of cell passages and incubation time. length of time required to induce MSC differentiation from adipose tissue to osteoblasts. In general, osteogenic differentiation is divided into three stages: cell proliferation, extracellular matrix maturation and matrix mineralization. Cell proliferation can occur on days 1-4, followed by maturation of extracellular matrix on days 5-14 and end with mineralization of the matrix on days 14-28. Mineralization can be detected since the 14th day of induction and increased to 21 days. Generally, mineralization begins after osteoblast proliferation and formation of extracellular matrix (mostly collagen). Previous studies have suggested that mineralization may increase in speed as cell proliferation slows due to high cell density.

In this study, since induction of osteogenesis on day 1 , most of the positive Alizarin red staining results can already be seen. After being cultured for one day in osteogenic differentiation media, the cells of the three passages have begun to change from the initial morphology, i.e. fibroblasts to slightly round. After incubation for 7 days, a number of mineralized nodules can be observed and an increase in cell volume in passages 10 and 15. A number of studies have shown that cell volume

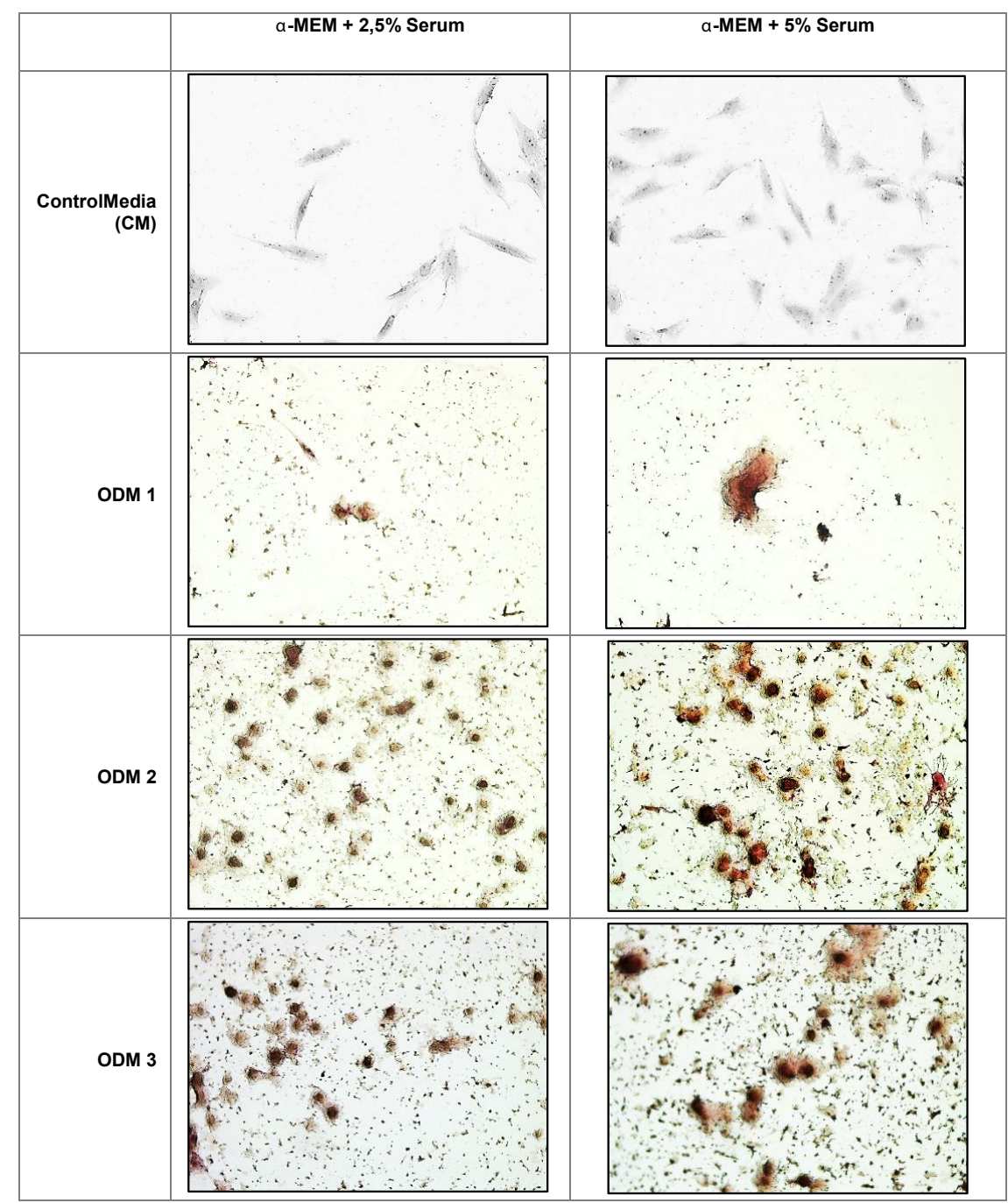

Figure 2: MSCs staining results of adipose tissue for osteogenic media optimization. MSCs were cultured in six different osteogenic media for five days and stained by using $1 \%$ Alizarin red dye. 
changes are a component of many cellular functions, including epithelial transport, metabolism, hormone release, migration, proliferation and cell growth and cell death (Figure 3).

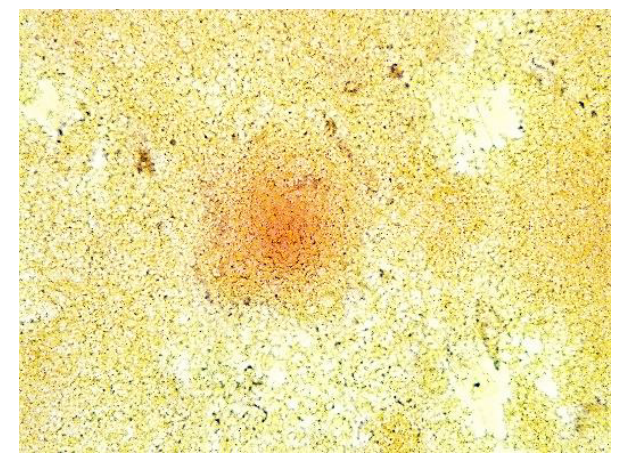

Figure 3: MSC cultures in passage 10 that have been incubated in ODM2 for 14 days. Images taken using 400x magnification.
In general, cell volume regulation does have an important role in cell proliferation and growth, but the role of cellular volume regulation in osteoblast lineages remains unclear. Furthermore, at the 14th incubation day, the mineralized nodule density becomes more stable at passage 10 , indicating that the cell has reached a relatively stable differentiated condition (Figure 4). During the incubation period of 14 days, the cells in passage 2 showed no significant change when compared with other passages, while the cells in passage 15 showed an increase that could still be seen daily. On the 14th day, cell cultures in passage 10 have reached a confluence, so when compared with cell cultures in passages 5 and 15, passage 10 images are seen taken with smaller magnification. Figure 3 shows the osteogenic differentiation picture of MSC passage 10 with 400x magnification.

Based on the results of this study, the MSC of the adipose tissue in passage 2 had the fewest number of cells and the differentiated ability to be the lowest osteoblast. As explained by Kuznetsov et al. and Satomura et al. $[26,40]$ the colonies obtained when planting MSCs in the initial passage are heterogeneous colonies in size, morphology and potential to differentiate into osteoblasts. In this study, cultures in the early

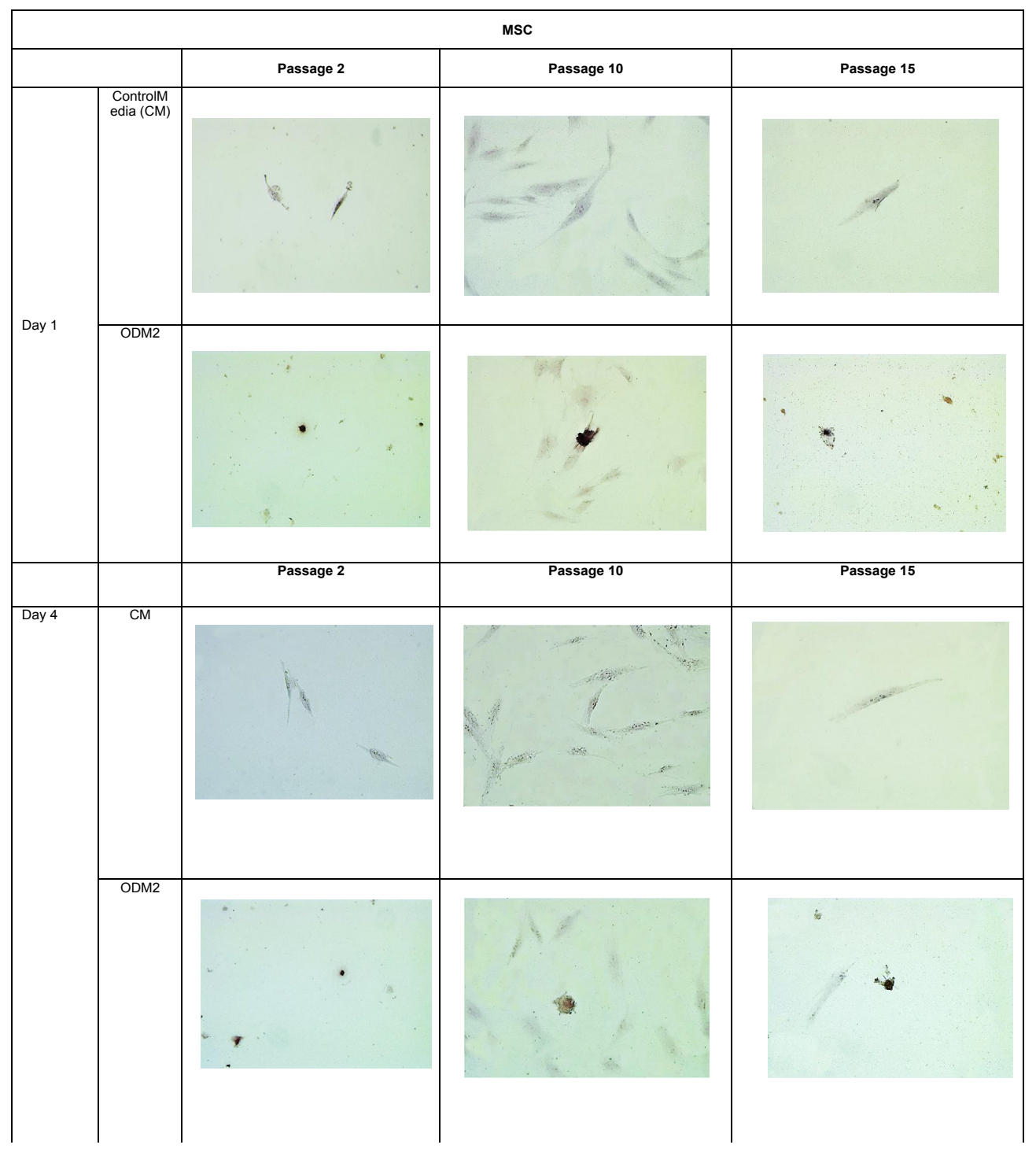




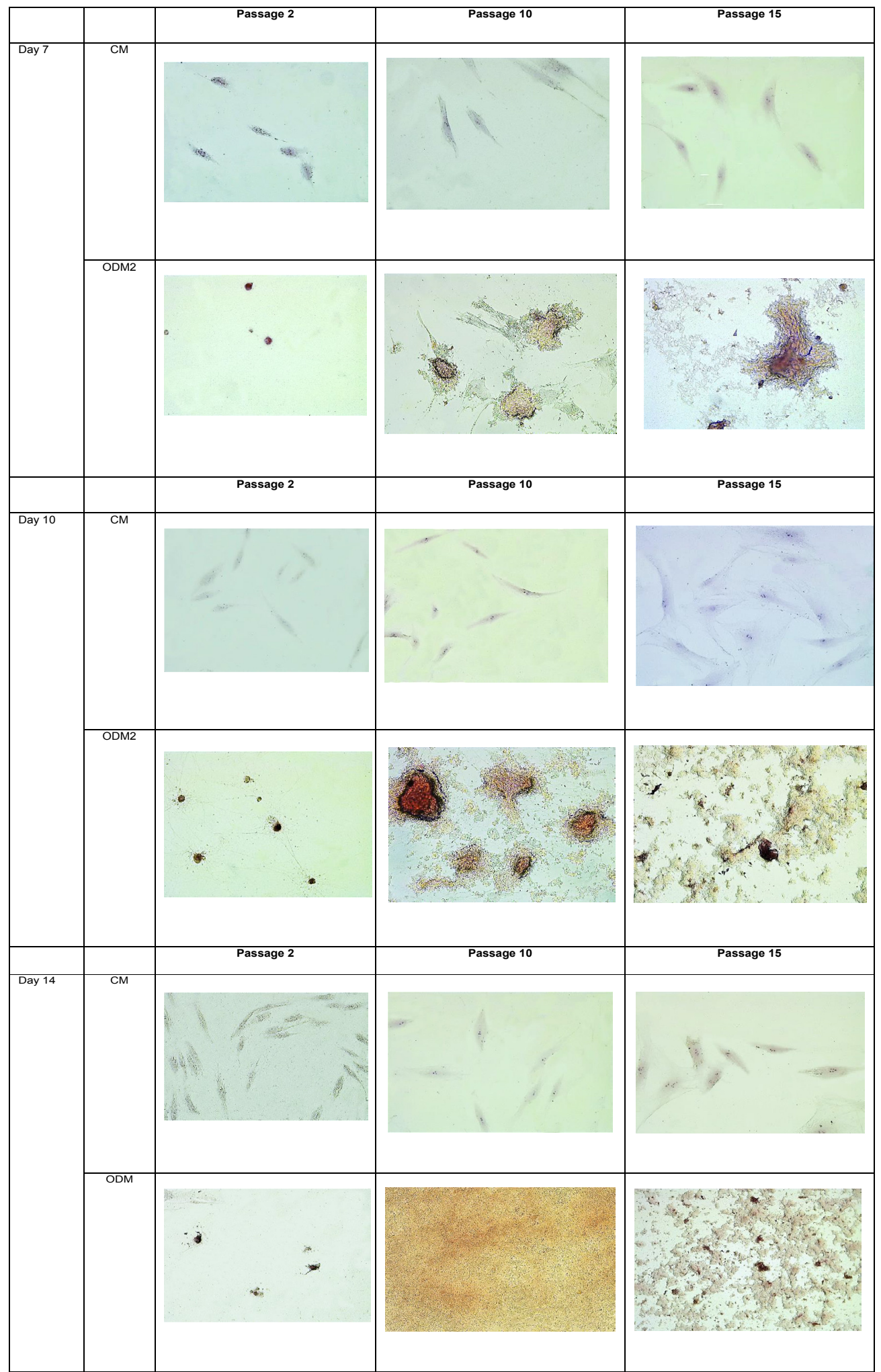

Figure 4: Comparison of osteogenic potential of MSC of origin of adipose tissue on the initial, middle and old passages. All photos with 200x magnification.

passages were also heterogeneous in the potential to differentiate into osteoblasts in cultures, so the osteogenic potential of MSCs were not equal. In addition, when MSCs were first cultured in vitro, the MSCs still retains the characteristics of its stem cells and takes time to adapt to new environmental conditions, thus making it difficult to differentiate. This can then be the cause of osteogenic potential of MSC in passage 2 
lower than other passages. On the other hand, in passage 10, the MSCs are able to differentiate into osteoblasts with relatively much greater number of cells than passages 2 and 15 because the MSCs has been adaptable and relatively stable in culture. The potential for osteogenic differentiation in passage 15 was sustained although the number of osteoblast cells formed is still less than in passage 10 . This is probably due to MSCs has undergone senescence, resulting in a decrease in cell proliferation capacity and may also lead to decreased osteogenic potential of MSCs, however it need further study .

Several studies have shown that the osteogenic activity of MSCs has decreased gradually as the passage increases. On the other hand, there are other studies suggesting that the osteogenic potential of MSC in the old passage can be maintained or even increased. Differences in the results of studies related to increased or decreased osteogenic ability of MSC with senescence are likely to occur due to differences in culture conditions and the lack of optimal in vitro testing to characterize osteogenesis completely. Turinetto et al. [43] found that increased cell death could result in higher levels of Alizarin red staining, resulting in misperceptions about increased osteogenic differentiation.

In the in vitro approach, the number of subcultures that the MSC can do without altering its characteristics significantly needs more attention. Kim et al. [25] suggests that in vitro (number of passages in culture) has a more significant effect on MSC differentiation than in vivo (donor physical). In this study, the MSC from adipose tissue managed to maintain its differentiation potential to passage 15 and increased the differentiation potential from passage 2 to passage 10 . The decrease in cell number in passage 15 could be caused by cell senescence. However, osteogenic differentiation can still occur in both the initial, middle and old passages. The results show that the osteogenic potential of MSC from adipose tissue does not decrease with age aging in vitro. This is an exciting discovery because the ability to repair damaged tissue will in reality decline with age.

\section{Summary}

Based on the results obtained, it can be concluded that the MSC was able to maintain its osteogenic potential until passage 15 . The result of osteogenic differentiation by using a-MEM culture medium supplemented with 5\% serum and dexamethasone, ascorbic acid and beta-glycerophosphate indicate that passage 10 (middle passage) has the best osteogenic potential compared to other passages, while the lowest osteogenic potential is seen in MSC passage 2.

\section{References}

1. Aksu AE, Rubin JP, Dudas JR, Marra KG (2008) Role of gender and anatomical region on induction of osteogenic differentiation of human adipose-derived stem cells. Ann Plast Surg 60: 306-322. [PubMed]

2. Baek WY, Lee MA, Jung JW, Kim SY, Akiyama H (2009) Positive regulation of adult bone formation by osteoblast-specific transcription factor osterix. J Bone Miner Res 24: 1055-1065. [PubMed]

3. Bianco $P$ (2007) Self-renewing mesenchymal progenitors in the bone marrow and in other mesodermal tissues. J. Stem Cells Regen Med 1: 44. [PubMed]

4. Bieback K, Kern S, Kocaomer A, Ferlik K, Bugert P (2008) Comparing mesenchymal stromal cells from different human tissues: bone marrow, adipose tissue and umbilical cord blood. Biomed Mater Eng 18: S71-S76.

5. Birmingham E, Niebur G, McHugh PE, Shaw G, Barry FP (2012) Osteogenic differentiation of mesenchymal stem cells is regulated by osteocyte and osteoblast cells in a simplified bone niche. Euro Cell Mater 23: 3-27. [PubMed]

6. Carson JS, Bostrom MP (2007) Synthetic bone scaffolds and fracture repair. Injury, 38: S33-S37. [PubMed]

7. Chang YJ, Tseng CP, Hsu LF, Hsieh TB, Hwang SM (2006) Characterization of two populations of mesenchymal progenitor cells in umbilical cord blood. Cell Biol Int 30: 495-499. [PubMed]

8. Choi KM, Seo YK, Yoon HH, Song KY, Kwon SY (2008) Effect of ascorbic acid on bone marrow-derived mesenchymal stem cell proliferation and differentiation. J Biosci Bioeng 105: 586-594.

9. D'Aniello C, Cermola F, Patriarca EJ, Minchiotti G (2017) Vitamin C in Stem Cell Biology: Impact on Extracellular Matrix Homeostasis and Epigenetics. Stem Cells Inter: 16. [PubMed]

10. Girolamo L, Lopa S, Arrigoni E, Sartori MF, Baruffaldi PFW (2009) Human adipose-derived stem cells isolated from young and elderly women: their differentiation potential and scaffold interaction during in vitro osteoblastic differentiation. Cytotherapy 11: 793-803. [PubMed]

11. Girolamo L, Sartori MF, Albisetti W, Brini AT (2007) Osteogenic differentiation of human adipose-derived stem cells: comparison of two different inductive media. J Tissue Eng Regen Med 1: 154-157.

12. Deng ZL, Sharff KA, Tang N, Song WX, Luo J (2008) Regulation of osteogenic differentiation during skeletal development. Front Biosci 13: 2001-2021. [PubMed]

13. DiMarino AM, Caplan Al, Bonfield TL (2013) Mesenchymal stem cells in tissue repair. Front Immunol, 4: 201. [PubMed]

14. Dijke P, Krause C, de Gorter DJ, Löwik CG, Bezooijen RL (2008) OsteocyteDerived Sclerostin Inhibits Bone Formation: Its Role in Bone Morphogenetic Protein and Wnt Signaling. J Bone Joint Surg 90: 31-35. [PubMed]

15. Doll B, Aleef M, Hollinger JO (2008) Overview of Fracture Repair. In W. S Pietrzak, Musculoskeletal Tissue Regeneration: Biological Materials and Methods. Chicago: Humana Press : 39-40. [PubMed]

16. Egusa H, lida K, Kobayashi M, Lin TY, Zhu M, Zuk PA (2007) Downregulation of extracellular matrix-related gene clusters during osteogenic differentiation of human bone-marrow and adipose tissue-derived stromal cells. Tissue Eng 13 2589-2600. [PubMed]

17. Friedenstein AJ (1990) Osteogenic stem cells in the bone marrow. In N. M. Heersche, \& J. A. Kanis, Bone and Mineral Research. Amsterdam: Elsevier Science Publishers B. V. Biomedical Division: 243-270. [PubMed]

18. Goldstein SA (2006) Tissue engineering solutions for traumatic bone loss. J Am Acad Orthop Surg 14: S152-S156. [PubMed]

19. Gordeladze JO, Drevon CA, Syversen U, Reseland JE (2002) Leptin stimulates human osteoblastic cell proliferation, de novo collagen synthesis, and mineralization: Impact on differentiation markers, apoptosis, and osteoclastic signaling. J Cell Biochem 85: 825-836. [PubMed]

20. Gronthos S, Graves SE, Ohta S, Simmons PJ (1994) The STRO-1+ fraction of adult human bone marrow contains the osteogenic precursors. Blood 84 : 4164-4173. [PubMed]

21. Hutmacher DW, Schantz JT, Lam CX, Tan C, Lim TC (2007) State of the art and future directions of scaffold-based bone engineering from a biomaterials perspective. J Tissue Eng Regen Med 1: 245-260.

22. Jaiswal N, Haynesworth SE, Caplan Al, Bruder SP (1997) Osteogenic differentiation of purified, culture expanded human mesenchymal stem cells in vitro. Cell Biochem 64: 295-312.

23. Kaveh K, Ibrahim R, Bakar ZA, Ibrahim TA (2011) Mesenchymal Stem Cells Osteogenic Lineage and Bone Tissue Engineering: A Review. J Ani Veter Adv 10: 2317-2330. [PubMed]

24. Kern S, Eichler H, Stoeve J, Klüter H, Bieback K (2006) Comparative analysis of mesenchymal stem cells from bone marrow, umbilical cord blood, or adipose tissue. Stem Cell Dayt. Ohio 24: 1294-1301. [PubMed]

25. Kim YH, Yoon DS, Kim HO, Lee JW (2012) Characterization of different subpopulations from bone marrow-derived mesenchymal stromal cells by alkaline phosphatase expression. Stem Cells and Develop 21: 2958-2968.

26. Kneser U, Schaefer DJ, Polykandriotis E, Horch RE (2006). Tissue engineering of bone: the reconstructive surgeon's point of view. J Cell Mol Med 10: 7-19. [PubMed]

27. Landis WJ, Silver FH (2009) Mineral deposition in the extracellular matrices of vertebrate tissues: Identification of possible apatite nucleation sites on type I collagen. Cells Tissues Organs 189: 20-24. [PubMed]

28. Langenbach F, Handschel J (2013) Effects of dexamethasone, ascorbic acid 
Citation: Rilianawati R, Bratakencana J, Harlim A (2018) Differentiation Potential of Adipose-Derived Mesenchymal Stem Cells to Osteoblast Cell in Early, Middle and Late Passages. J Stem Cell Res Ther 8: 426. doi: 10.4172/2157-7633.1000426

and $\beta$-glycerophosphate on the osteogenic differentiation of stem cells in vitro. Stem Cell Res Ther 4: 117. [PubMed]

29. Lian JB, Stein GS (1995) Development of the osteoblast phenotype: Molecular mechanism mediating osteoblast growth and differentiation. lowa Orthop J 15 : 118-140.

30. Long F (2011) Building strong bones: Molecular regulation of the osteoblastic lineage. Nat Rev Mol Cell Biol 13: 27-38

31. Maehata, Y., Takamizawa, S., Ozawa, S., Izukuri, K., Kato, Y., Sato, S., . . Hata, R. (2007). Type III collagen is essential for growth acceleration of human osteoblastic cells by ascorbic acid-2-phosphate, a long acting vitamin $\mathrm{C}$ derivative. Matrix Biol, 26, 371-381. [PubMed]

32. Matthews S, Bhonde R, Gupta PK, Totey S (2012). Extracellular matrix protein mediated regulation of the osteoblast differentiation of bone marrow derived human mesenchymal stem cells. Differentiation 84: 185-192.

33. Meyer U, Wiesmann HP (2006) Bone and Cartilage Engineering. Berlin Heidelberg: Springer. [PubMed]

34. Millan JL (2013) The role of phosphatases in the initiation of skeleta mineralization. Calcif Tissue Int 93: 299-306. [PubMed]

35. Murshed M, McKee MD (2010) Molecular determinants of extracellular matrix mineralization in bone and blood vessels. Curr Opin Nephrol Hypertens, 19: 359-365. [PubMed]

36. Peptan IA, Hong L, Mao JJ (2006) Comparison of osteogenic potentials of visceral and subcutaneous adipose-derived cells of rabbits. Plastic and Reconstructive Surgery 117: 1462-1470. [PubMed]

37. Porter RM, Huckle WR, Goldstein AS (2003) Effect of dexamethasone withdrawal on osteoblastic differentiation of bone marrow stromal cells. Cell Biochem 90: 13-22. [PubMed]

38. Qiao XY, Nie Y, Ma YX, Chen Y, Cheng R (2016) Irisin promotes osteoblast proliferation and differentiation via activating the MAP kinase signaling pathways. Sci Rep 16: 18732. [PubMed]

39. Samee N, Geoffroy V, Marty C, Schiltz C, Vieux-Rochas M (2008) Dlx5 a Positive Regulator of Osteoblastogenesis, is Essential for OsteoblastOsteoclast Coupling. Am J Pathol 173: 773-780.

40. Shafiee A, Seyedjafari E, Soleimani M, Ahmadbeigi N, Dinarvand P (2011) A comparison between osteogenic differentiation of human unrestricted somatic stem cells and mesenchymal stem cells from bone marrow and adipose tissue. Biotechnol Lett 33: 1257-1264. [PubMed]

41. Stein GS, Lian JB, Owen TA (1990) Relationship of cell growth to the regulation of tissue-specific gene expression during osteoblast differentiation. FASEB 13: 3111-3123. [PubMed]

42. Takarada T, Hinoi E, Nakazato R, Ochi H, Xu C (2013) An analysis of skeleta development in osteoblast-specific and chondrocyte-specific runt-related transcription factor-2 (Runx2) knockout mice. J Bone Miner Res 28: 2064-2069.

43. Turinetto, V., Vitale, E., \& Giachino, C. (2016). Senescence in Human Mesenchymal Stem Cells: Functional Changes and Implicatons in Stem CellBased Therapy. Int J Mol Sci, 17, 1164.

44. Vimalraj S, Arumugam B, Miranda PJ, Selvamurugan N (2015) Runx2: Structure, function and phosphorylation in osteoblast differentiation. Int $\mathrm{J}$ Biol Macromol 78: 202-208. [PubMed]

45. Wall ME, Bernacki SH, Loboa EG (2007) Effects of serial passaging on the adipogenic and osteogenic differentiation potential of adipose-derived human mesenchymal stem cells. Tissue Eng 13: 1291-1298. [PubMed]

46. Wang H, Pang B, Li Y, Zhu D, Pang T (2012) Dexamethasone has variable effects on mesenchymal stromal cells. Cytotherapy 14: 423-430. [PubMed]

47. Wang Y, Azais T, Robin M, Vallee A, Catania C (2012) The predominant role of collagen in the nucleation, growth, structure and orientation of bone apatite. Nat Mater 11: 724-733. [PubMed]

48. Zhu M, Kohan E, Bradley J, Hedrick M, Benhaim P, Zuk P (2009) The effect of age on osteogenic, adipogenic and proliferative potential of female adiposederived stem cells. J Tissue Eng Regen Med 3: 290-301.

49. Zoch ML, Clemens TL, Riddle RC (2016) New insights into the biology of osteocalcin. Bone 82: 42-44. [PubMed]

50. Zuk, P. A. (2009). The intracellular distribution of the ES cell totipotent markets Oct4 and Sox-2 in adult stem cells differ dramatically according to commercia antibody used. J Cell Biochem 106: 867-877.

51. Zuk PA, Chou YF, Mussano F, Benhaim P, Wu BM (2011) Adipose-derived stem cells and BMP2: part 2. BMP2 may not influence the osteogenic fate of human adipose-derived stem cells. Connect Tissue Res 52: 119-132. [PubMed] 